\title{
MEANINGFUL LEARNING USING CONCEPT MAPS AS
}

\section{A LEARNING STRATEGY}

\author{
Carmen Romero $^{1}$ iD, Moisés Cazorla ${ }^{[}$, Olga Buzón ${ }^{1}$ iD \\ ${ }^{1}$ Universidad Internacional de la Rioja (Spain) \\ ${ }^{2}$ Colegio ValdeSerra (Spain)
}

mariadelcarmen.romero@unir.net, mcazorla@,colegiovaldeserra.com, olga.buzon@unir.net

Received March 2017

Accepted July 2017

\section{Abstract}

This work presents a proposal for the teaching-learning of the concept map technique applied to the Natural Sciences course in the second year of Compulsory Secondary Education (ESO, according to its initials in Spanish). Two sessions have been designed, one of which is an instructor-led session to learn the technique and another is a session in which the students independently create a concept map, applying what they have learned in the previous session. To determine the effectiveness of the proposal, the concept maps created by the students during the two sessions have been evaluated, the grades obtained on the assessment tests for the unit before the concept map experience have been compared to those obtained on the assessment tests for the unit carried out using this technique, and a survey was written to find out the level of student satisfaction with the training received and the usefulness of the concept map technique. The results show that more than $65 \%$ of students earned grades between 7 and 9.5 on the concept maps created independently during the two academic years in which the proposal has been implemented. The study carried out allows us to conclude that the students have learned how to create concept maps, and evidences the usefulness of the methodology used and the need to implement more sessions for the creation of concept maps in the Natural Sciences course so that this technique is transformed into a learning strategy. The students have expressed a high level of satisfaction with the training received and the tool they have learned how to use.

Keywords - Significant learning, Learning strategy, Concept maps. 


\section{Introduction}

In today's Knowledge Society, teaching at the Compulsory Secondary Education (ESO) level must promote the students' capacity for autonomous learning and the learning to learn competence. It is believed that an essential way to achieve this involves the use of effective study techniques so that students can incorporate them into their learning processes, transforming them into learning strategies that enable them to transform rote learning into significant learning (Andueza, 2016).

Current legislation pertaining to Compulsory Secondary Education in Spain, Orden ECD/65/2015, of 21 January, defines the key competences that students must acquire for each of the different academic years. This work intends to highlight the importance of the learning to learn competence, which is associated with having the skills to initiate learning and being capable of continuing to learn in an increasingly more effective and autonomous manner, based on one's objectives and needs. Martín (2010) indicated that this competence "means acquiring certain metacognitive skills, i.e., skills that enable the student to know and regulate his or her own learning processes" (pp. 1).

In order for students to be able to know and regulate their learning processes, it is essential for them to use appropriate study techniques. We could define study techniques as a set of tools used with the aim of helping to improve learning, attempting to facilitate studying and make it more effective, thus maximizing academic performance. According to Calero (2009), "when used properly, study techniques optimize learning, (...) those who study a single subject using three, four, five or more techniques will have increasingly greater academic achievements" (pp. 23-24).

On the other hand, learning strategies can be defined as the procedures we use in a conscious, controlled and intentional manner as instruments to facilitate learning and solve problems (DíazBarriga \& Hernández, 2002).In this sense, the intentional use of study techniques for the purpose of making learning more efficient makes them particular learning strategies, which eventually come to be used in a conscious manner in the studying and learning process.

There is currently great disparity in terms of how the classifications of learning strategies are used. Bernardo (2004) proposes a classification based on thought phases, establishing eight types of strategies. This work falls within the strategies for organizing and understanding information, which correspond to the reflective phase. This is a crucial phase for the correct cognitive 
development of students, in which the organization and comprehension of the information received occurs so that it can be transformed into knowledge.

Of all the study techniques associated with the reflective phase in the present work, concept maps have been chosen as the subject of study. Concept maps are a graphic technique created in 1972 by Josep D. Novak, showing information organized hierarchically and the relationships among concepts in a graphic form. Novak and Gowin (1988) define concept maps as "a schematic resource for representing a set of conceptual meanings included in a structure of propositions" (p. 19). They can be considered as a network of concepts, with the main concept or idea placed at the top, normally inside an oval, while the rest of the more specific concepts are organized on the map in descending order of importance or specificity. The concepts are associated with one another through linking words that join the concepts to give them significance. Two or more concepts joined by linking words form a proposition with a certain meaning. Most conceptual meanings are learned through the composition of propositions that include the concept that is to be acquired (Aguilar, 2006; Novak, 2013). When students apply this technique, the new knowledge is assimilated by establishing links to previous, pre-existing knowledge, which acts as an anchor for the new concepts that are included in the cognitive structure and become defined and differentiated knowledge that enriches the network of meanings and expands the learning matrix (Novak, Mintzes \& Wandersee, 2005). When the new content is learned this way, it is less vulnerable to being forgotten and it will be easier to retain (Novak, 2011; Romance \& Vitale, 2013). In this sense, concept maps are the perfect instrument for measuring significant knowledge acquisition, as they make it possible to analyze how wellstructured the knowledge is and how valid the relationships are that are established within the new knowledge (Edmonson, 2005).

The incorporation of concept maps in the instructional design makes it possible to abandon rote learning in favor of reflective thought in which ideas are organized sequentially, establishing new relationships among concepts and therefore new meanings, thus facilitating significant learning through the organization and comprehension of information (Mendonça, 2013; Gallego, Crisol \& Gámiz, 2013). Besides boosting creativity, concept maps can also have a positive effect on such important aspects for learning as self-esteem and motivation. Furthermore, they reveal conceptual errors; once these are recognized, conceptual change can be promoted (Lucas-Molina, Pérez-Albéniz, Fonseca-Pedrero, Ortuño-Sierra, Urraca \& Santarén-Rosell, 2017). 
The use of concept maps as a technique to promote significant learning is not a new strategy, as evidenced by their application at different educational levels (Adesope \& Nesbit, 2009; De Benito, Darder \& Salinas, 2012; Kinchin, 2014; Vázquez \& López, 2016). For this reason, this work has chosen to present the implementation of a methodology for creating and evaluating concept maps by students in secondary education, with the intent of teaching them the technique and it being incorporated as a learning strategy.

\section{Aim}

The primary objective of this work is to analyze the use of concept maps as a learning strategy in the Natural Sciences course during the second year of Compulsory Secondary Education (ESO), studying the criteria for their creation and evaluation. The intent is to foster an improvement in the students' teaching-learning process, teaching them how to correctly create concept maps and attempting to introduce them in their studying and learning dynamics. Likewise, this work also intends to study student satisfaction with the technique learned.

\section{Methodology}

\subsection{Recipients}

The teaching proposal presented in this work targets students in the Natural Sciences course during the second year of Compulsory Secondary Education (ESO) at Val de Serra School in Almería, Spain. It has been implemented for two academic years, during the 2014/2015 school year with a group consisting of 18 students (13 girls and 5 boys) between 13 and 14 years of age, and during the 2015/2016 school year with a group consisting of 24 students (12 girls and 12 boys) between 13 and 14 years of age. In general, the selected students showed a high level of mastery of the English language and a medium-high level in all subject areas. The students study 3 subjects entirely in English during the present course: English Language, Natural Sciences and Physical Education. 


\subsection{Instructional design}

\subsubsection{Creation of concept maps}

Based on the criteria established by Novak (1998), the steps were designed that must be followed to create a concept map based on a text (Table 1).

\begin{tabular}{|c|c|}
\hline Stages established by Novak & Stages established to create a concept map \\
\hline $\begin{array}{l}\text { Identify focus questions regarding the topic } \\
\text { that you wish to represent with the map. Based } \\
\text { on this question, identify } 10 \text { to } 20 \text { concepts } \\
\text { that are pertinent and make a list with them. }\end{array}$ & $\begin{array}{l}\text { 1. Read the text. } \\
\text { 2. Underline the main ideas of the text. } \\
\text { 3. Identify the main concepts and make a list } \\
(10-15 \text { concepts). }\end{array}$ \\
\hline $\begin{array}{l}\text { Organize the concepts on the list, placing the } \\
\text { largest or most general at the start and the } \\
\text { most specific in descending order. } \\
\text { Review the list and add more concepts, if } \\
\text { necessary. }\end{array}$ & $\begin{array}{l}\text { 4. Organize the concepts in order of relevance } \\
\text { (the most general at the beginning of the list, } \\
\text { and the most specific or subordinate at the end). }\end{array}$ \\
\hline $\begin{array}{l}\text { Begin to build the map, placing the general } \\
\text { concept or concepts at the top. }\end{array}$ & $\begin{array}{l}\text { 5. Place the concepts horizontally on a blank } \\
\text { sheet in hierarchical order (the most general at } \\
\text { the top, and the most specific at the bottom). }\end{array}$ \\
\hline $\begin{array}{l}\text { Select several subconcepts and place them } \\
\text { under the general concept(s), creating } \\
\text { successive hierarchical levels in order of } \\
\text { relevance. }\end{array}$ & \\
\hline $\begin{array}{l}\text { Draw lines to join the concepts.Label these } \\
\text { lines with one or more linking words that } \\
\text { define the relationship between the connected } \\
\text { concepts, generating propositions. }\end{array}$ & $\begin{array}{l}\text { 6. Draw lines to join the concepts. } \\
\text { 7. Enter words on the lines to define the } \\
\text { relationship between concepts and generate } \\
\text { propositions that give meaning. }\end{array}$ \\
\hline $\begin{array}{l}\text { Modify the map structure (adding, deleting or } \\
\text { changing concepts) as necessary. }\end{array}$ & \\
\hline $\begin{array}{l}\text { Search for links among concepts on different } \\
\text { parts of the map and label the lines with } \\
\text { linking words that create meaning between the } \\
\text { concepts. }\end{array}$ & $\begin{array}{l}\text { 8. Join concepts from different parts of the map } \\
\text { with lines and linking words that generate new } \\
\text { meaningful propositions. }\end{array}$ \\
\hline
\end{tabular}

Table 1. Steps to follow to create a concept map (Novak,1998, pp. 283-284)

As an introduction to learning how to create a concept map, an activity called the "Concept Map Experience" has been designed that was completed in two 60-minute classroom sessions.

A first session to learn how to create a concept map has been designed. To implement this session, an expository and operational-participatory methodology was used, in which the instructor guided the students through each of the steps described above. To accomplish this, a PowerPoint presentation was created that initially explains the basics of concept maps and gives a simple example of how to create a concept map based on a text, following the steps shown in Table 1. The presentation must be done in a progressive, guided manner. After the explanation of each of the steps to follow to create a concept map, the students should be given time to work 
individually in the classroom to carry out the corresponding step, with the instructor showing afterwards how it would look in the presentation. Figure 1 shows a template explaining the first session.

\section{SESSION 1: CREATING A CONCEPT MAP BASED ON A TEXT}

\section{OBJECTIVES:}

To create a concept map based on a text.

To promote the learning to learn competence, in addition to autonomy and personal initiative.

To develop the students' graphic abilities and creativity.

To promote the capacity for synthesis and comprehension of information.

To promote the ability to structure information.

\section{APPROACH AND IMPLEMENTATION OF THE ACTIVITY:(60 minutes)}

Students are seated individually in the classroom.

- The instructor gives the students a printout of Activity 1, consisting of a text in English, entitled "Trophic levels in an ecosystem", the steps for completing the activity and 2 blank sheets of paper to do the activity.

- $\quad$ Step 1 (students): the students read the text.

- $\quad$ Step 2 (students): the students underline the key ideas, guided by key questions written by the instructor.

- Steps 1 and 2 (instructor): the instructor explains the main key ideas of the text in a PowerPoint presentation.

- Steps 3 and 4 (students): the students locate the key concepts (10-15) and organize them in order of relevance (from most general to most specific).

- Steps 3 and 4 (instructor): the instructor shows how to locate the key concepts and how to create a list of concepts.

- Step 5 (students): the students place the concepts on a blank sheet of paper according to levels of hierarchic importance (from more general to more specific).

- Step 6 (students): the students draw lines, joining the concepts.

- Steps 5 and 6 (instructor): the instructor shows his or her way of positioning and joining the concepts, aided by the guided, progressive and animated PowerPoint presentation.

- Step 7 (students): the students enter the linking words between the concepts, establishing relationships between them and generating propositions.

- Step 7 (instructor): the instructor shows his or her way of entering the key words and generating propositions, aided by the presentation.

- Step 8 (students):the students enter cross links that relate the concepts belonging to different hierarchical branches of the concept map.

- Step 8 (instructor): the instructor shows his or her way of entering the cross links on the map, aided by the presentation.

The instructor proceeds to collect the maps created to evaluate them and hands out a copy of the list of key concepts and concept map he or she created based on the text and shown in the PowerPoint presentation used.

Figure 1. Session to learn how to create a concept map

A second session has subsequently been implemented, in which the students practice what they have learned and individually develop a concept map, following the steps set out in Figure 1. 


\subsubsection{Evaluation of the concept maps}

To evaluate the concept maps developed in sessions 1 and 2, a rubric has been designed, which is presented in Table 2. After each of the sessions explained above, the instructor hands out the evaluated maps to the students with the corresponding comments. Five minutes are spent on explaining the main deficiencies observed when correcting the maps and the main ways in which they can be improved, for students to take into account when creating future concept maps and thus improving this technique.

\begin{tabular}{|c|c|c|c|c|c|}
\hline Criteria & $\begin{array}{l}\text { Excellent } \\
(20 \text { points })\end{array}$ & $\begin{array}{c}\text { Satisfactory } \\
\text { (15 points) }\end{array}$ & $\begin{array}{l}\text { Average } \\
\text { (10 points) }\end{array}$ & $\begin{array}{c}\text { Needs } \\
\text { improvement } \\
(5 \text { points })\end{array}$ & $\begin{array}{l}\text { Points } \\
\text { earned }\end{array}$ \\
\hline $\begin{array}{c}\text { Concepts and } \\
\text { ideas }\end{array}$ & $\begin{array}{l}\text { Establishes and } \\
\text { synthesizes the } \\
\text { main concepts and } \\
\text { ideas of the text. }\end{array}$ & $\begin{array}{l}\text { The general ideas or } \\
\text { concepts of the text } \\
\text { are partially } \\
\text { indicated. }\end{array}$ & $\begin{array}{l}\text { The basic ideas or } \\
\text { contents of the text } \\
\text { are not indicated. }\end{array}$ & $\begin{array}{l}\text { Reflects some ideas } \\
\text { from the text, but } \\
\text { not the main ones. }\end{array}$ & \\
\hline $\begin{array}{l}\text { Relationship } \\
\text { between } \\
\text { concepts }\end{array}$ & $\begin{array}{l}\text { Correctly } \\
\text { establishes the } \\
\text { relationships } \\
\text { between the main } \\
\text { ideas or concepts. }\end{array}$ & $\begin{array}{l}\text { The relationships } \\
\text { shown on the } \\
\text { concept map are } \\
\text { moderately } \\
\text { acceptable. }\end{array}$ & $\begin{array}{l}\text { Most of the } \\
\text { relationships } \\
\text { between concepts } \\
\text { are not well defined. }\end{array}$ & $\begin{array}{l}\text { The relationships } \\
\text { shown on the } \\
\text { concept map are } \\
\text { unacceptable. }\end{array}$ & \\
\hline Hierarchy & $\begin{array}{l}\text { The concepts or } \\
\text { ideas are arranged } \\
\text { in a logical } \\
\text { hierarchy, with the } \\
\text { most general } \\
\text { concepts at the top } \\
\text { and the subordinate } \\
\text { and specific ones at } \\
\text { the bottom. }\end{array}$ & $\begin{array}{l}\text { Most concepts or } \\
\text { ideas are arranged in } \\
\text { an acceptable } \\
\text { hierarchical order, } \\
\text { but the relationship } \\
\text { between them is not } \\
\text { well defined. }\end{array}$ & $\begin{array}{l}\text { Subordinate } \\
\text { concepts are } \\
\text { presented at the top } \\
\text { and general } \\
\text { concepts at the } \\
\text { bottom. }\end{array}$ & $\begin{array}{l}\text { The concepts are } \\
\text { presented without } \\
\text { any hierarchy. }\end{array}$ & \\
\hline Propositions & $\begin{array}{l}\text { The connectors } \\
\text { used with the } \\
\text { concepts facilitate } \\
\text { an excellent } \\
\text { relationship } \\
\text { between the two to } \\
\text { form propositions. }\end{array}$ & $\begin{array}{l}\text { Not all the } \\
\text { connectors used } \\
\text { with the concepts } \\
\text { are correct, and thus } \\
\text { the relationship } \\
\text { between them to } \\
\text { form propositions is } \\
\text { only good. }\end{array}$ & $\begin{array}{l}\text { Many of the } \\
\text { connectors used } \\
\text { with the concepts } \\
\text { are incorrect, which } \\
\text { results in a } \\
\text { relationship } \\
\text { between the two to } \\
\text { form propositions } \\
\text { that is not well } \\
\text { defined. }\end{array}$ & $\begin{array}{l}\text { The connectors } \\
\text { used are not correct } \\
\text { and thus } \\
\text { propositions are not } \\
\text { formed. }\end{array}$ & \\
\hline Spelling & $\begin{array}{l}\text { The concept map } \\
\text { contains no spelling } \\
\text { errors. }\end{array}$ & $\begin{array}{l}\text { The concept map } \\
\text { has some spelling } \\
\text { errors (maximum 3). }\end{array}$ & $\begin{array}{l}\text { The concept map } \\
\text { has quite a few } \\
\text { spelling errors } \\
\text { (maximum 6). }\end{array}$ & $\begin{array}{l}\text { The concept map } \\
\text { has a large number } \\
\text { of spelling errors } \\
\text { (more than } 6 \text { ). }\end{array}$ & \\
\hline \multicolumn{5}{|c|}{$\begin{array}{lll}\text { Total points earned } & \text { The }\end{array}$} & \\
\hline
\end{tabular}

Table 2. Rubric for evaluating concept maps

To calculate the final grade on the concept maps, divide the score on the rubric (maximum of 100 points) by 10 . 


\subsection{Evaluation of the concept map experience}

\subsubsection{Grades earned on the concept maps}

To evaluate the learning of the concept maps technique during the experience carried out in academic years 2014/2015 and 2015/2016, the grades earned by the students on the maps in sessions 1 and 2 were compared. Session 1 is considered to be dedicated to learning the technique and is guided by the instructor, while session 2 applies what was learned in session 1: students work autonomously to apply each of the steps learned in session 1 in order to create a concept map.

\subsubsection{Comparison of grades earned on the assessment tests before and after the concept map experience}

To determine whether the use of this technique affects the students' learning process, a comparative study was carried out on the average grades earned by students on the assessment test for the unit prior to that studied using concept maps and the unit in which this technique was used during the 2015/2016 academic year. To do this, the Student's test for dependent samples was applied, determining the $\mathrm{t}$ and $\mathrm{p}$ values. Likewise, a study of the correlation of the grades earned by the students on both assessment tests was also performed, determining the Pearson correlation coefficient.

\subsubsection{Satisfaction with the experience carried out}

To study the degree of satisfaction of the students with the study technique used and the sessions conducted, a questionnaire consisting of 20 closed-ended questions with a yes or no answer was drafted (Table 3). The first 10 questions enabled us to obtain information on the satisfaction with the training received in the two sessions dedicated to learning the technique. Following this, another 10 questions were included to gather information on its usefulness. Finally, a question was included about the courses in which the application of concept maps is the most useful. 


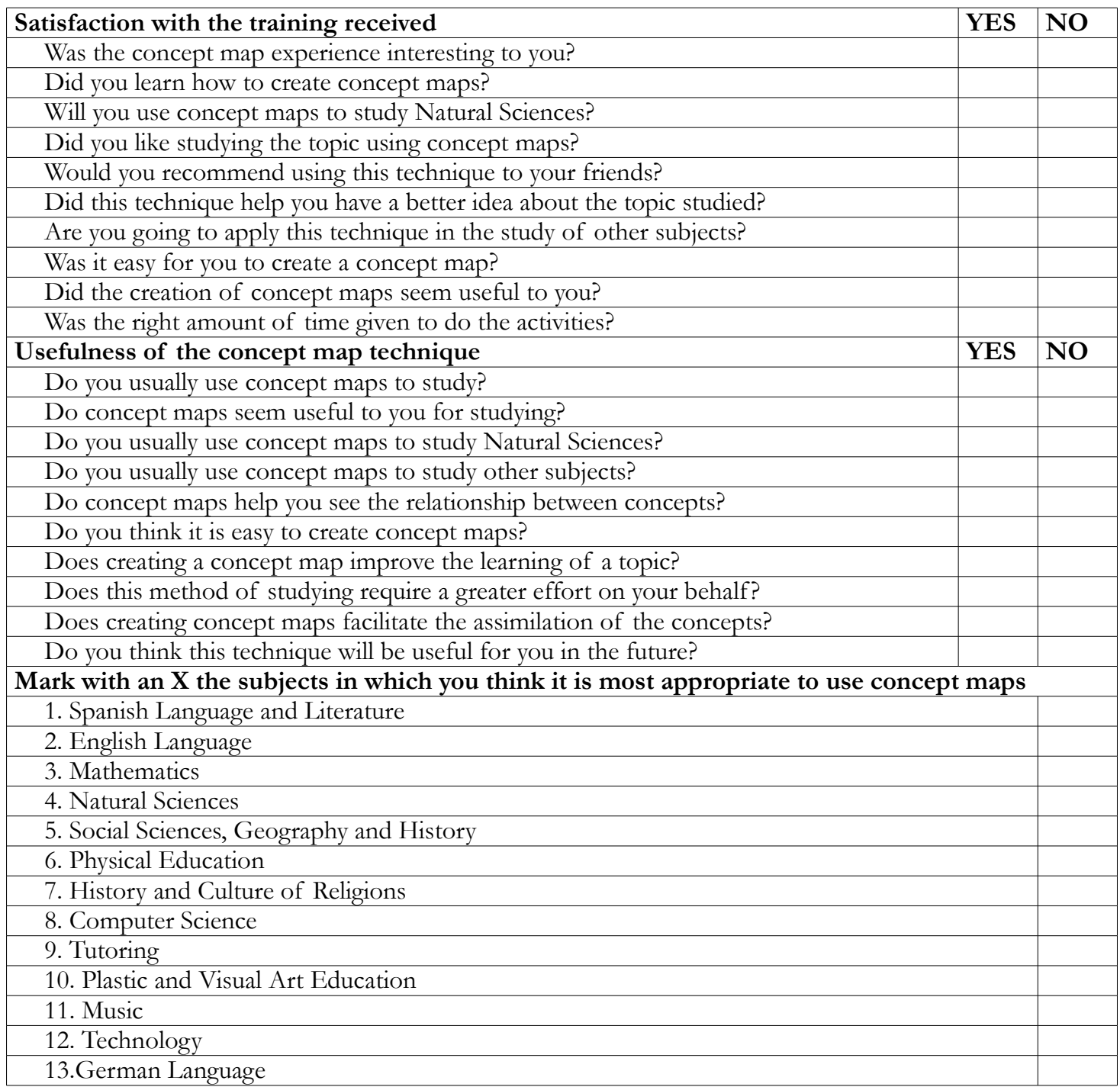

Table 3. Satisfaction questionnaire regarding the experience carried out and the usefulness of the technique learned

\section{Results}

\subsection{Grades earned on the concept maps}

The average grades earned on the concept maps during the two academic years in the two sessions dedicated to learning this technique are shown in Table 4. During the two academic years, it is observed that the average grades earned by students on the concept maps declined in session 2, with a sharper decline during the first academic year in which the experience was conducted. 


\begin{tabular}{|c|c|c|c|}
\hline & $\begin{array}{c}\text { Session } 1 \\
\text { 2014/15 academic year }\end{array}$ & $\begin{array}{c}\text { Session } 2 \\
\text { 2014/15 academic year }\end{array}$ & Differences \\
\hline $\mathrm{N}$ & 18 & 18 & \\
\hline Mean & 8.32 & 7.41 & 0.91 \\
\hline \multirow[t]{2}{*}{ Standard deviation } & 1.056 & 1.125 & 0.069 \\
\hline & $\begin{array}{c}\text { Session } 1 \\
2015 / 16 \text { academic year }\end{array}$ & $\begin{array}{c}\text { Session } 2 \\
2015 / 16 \text { academic year }\end{array}$ & Differences \\
\hline $\mathrm{N}$ & 24 & 24 & \\
\hline Mean & 7.67 & 7.06 & 0.61 \\
\hline Standard deviation & 1.46 & 1.60 & 0.14 \\
\hline
\end{tabular}

Table 4. Descriptive statistics for the concept map grades

The results obtained on the evaluation of the concept maps created by the students during the 2014/2015 academic year in activities 1 and 2 are shown in Figure 2.

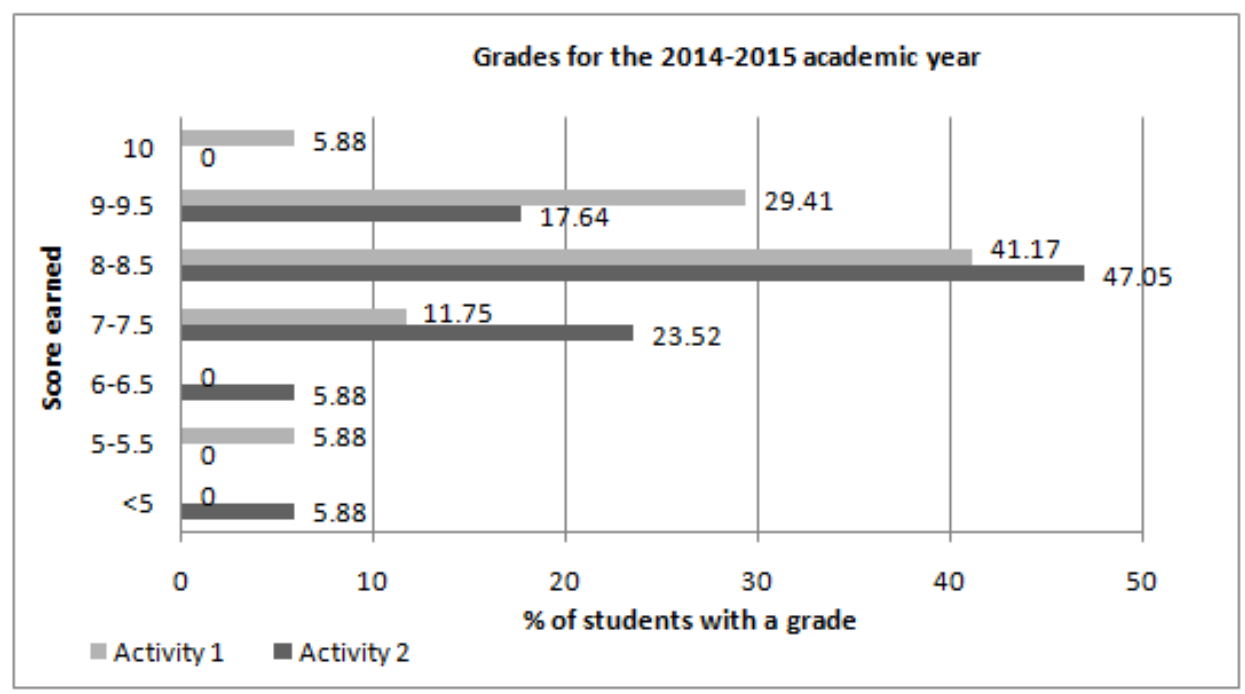

Figure 2. Grades earned by students on concept maps during the 2014/15 academic year

During the first session, $5.88 \%$ of the students earned a grade of 10 , while no students earned this grade during the second session. This same trend is observed with regards to grades of 9-9.5. A total of $29.41 \%$ of the students earned this grade in session 1, as compared to $17.65 \%$ in session 2. However, the percentage of students who earned a grade of 8-8.5 is the same for both sessions: $47.06 \%$. With regard to students who earned a grade of 7-7.5, the percentage was $11.76 \%$ in session 1 , and increased to $70 \%$ in session 2 . No students earned a grade of 6-6.5 in session 1 , while $5.88 \%$ of them earned this grade in session 2 . Finally, $5.88 \%$ of students earned a grade of 5-5.5 in session 1, while this same percentage earned a grade lower than 5 in session 2 . 
Figure 3 shows the results obtained by the students in this same experience for the 2015/16 academic year.

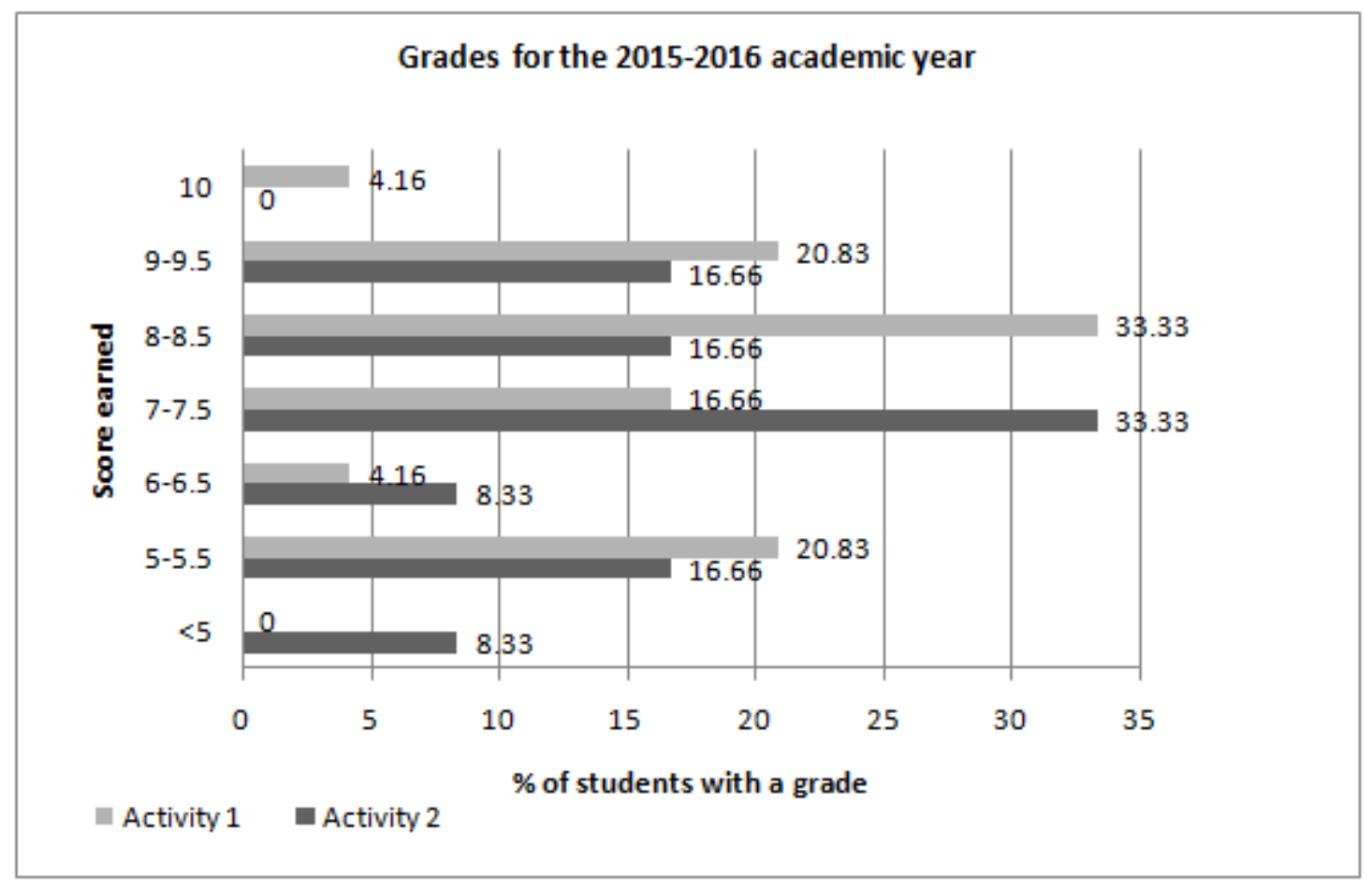

Figure 3. Grades earned by students on concept maps during the 2015/16 academic year

As can be seen in Figure 3, the percentage of students who earned a grade of 10 is $4.16 \%$ in session 1 , and $0 \%$ in session 2. During this academic year, the percentage of students who earned a grade of $9-9.5$ is very similar in sessions 1 and 2 (16.66\% and $20.83 \%$, respectively), with differences appearing in the grades in the range of $8-8.5$, $(33.33 \%$ in session 1 , as opposed to $16.66 \%$ in session 2). With regard to students who earned a grade of $7-7.5$, the percentage increased from $16.66 \%$ in session 1 to $33.33 \%$ in session 2. Furthermore, the percentage of students who earned a grade of 6-6.5 doubled in the second session, from $4.16 \%$ to $8.33 \%$. There are no differences in students who earned grades of 5-5.5 (29.41 and 23.53), but a difference was observed in those who had grades lower than 5 , which was 0 in session 1 and $12 \%$ in session 2.

The mean of the grades earned in each session during the two academic years makes it possible to state that most students have learned, in a general sense, the steps to follow to create a concept 
map. When the grades earned during the two academic years studied are compared, it is revealed that the grades earned in session 1 are higher than in session 2, with the difference being in the procedure used to conduct each activity, since session 1 is dedicated to learning the technique and it was guided by the instructor. The students completed a step and then the instructor showed them how he or she had done it, thus facilitating the rectification of the procedure carried out by the students. On the contrary, during session 2 the students completed all the steps to create the map consecutively; the maps were then collected and the instructor explained the steps followed to create the concept map, and thus the students had no opportunity to rectify any aspect of the map created during that particular session.

\subsection{Comparison of grades earned on the assessment tests before and after the concept map experience}

Table 5 shows the study carried out to compare the mean grades on the assessment tests before and after the concept map experience. The results of the statistical study carried out reveal that there are no significant differences between the mean grades on the assessment test administered in the unit before and after the application of the concept maps.

\begin{tabular}{|l|r|r|r|r|r|}
\hline & \multicolumn{1}{|c|}{$\begin{array}{c}\text { Test grades } \\
\text { before }\end{array}$} & \multicolumn{1}{|c|}{$\begin{array}{c}\text { Test grades } \\
\text { after }\end{array}$} & Differences & t & p-value \\
\hline $\mathrm{N}$ & 24 & 24 & & & \\
\hline Mean & 7.45 & 7.74 & 0.2917 & 1.3277 & 0.098 \\
\hline Standard deviation & 2.18 & 1.97 & 1.0762 & & \\
\hline Pearson correlation coefficient & \multicolumn{2}{|c|}{0.8704} & & & \\
\hline
\end{tabular}

Table 5. Statistical analysis of the grades on the assessment tests administered before and after the concept map experience

However, the graph showing the correlation among the grades (Figure 4) reveals that the students with grades between 6 and 8.5 on the first test after the experience have grades that are 1 point higher on the second test, which seems to show that those students with an intermediate academic level experience a slightly greater improvement following the experience. 


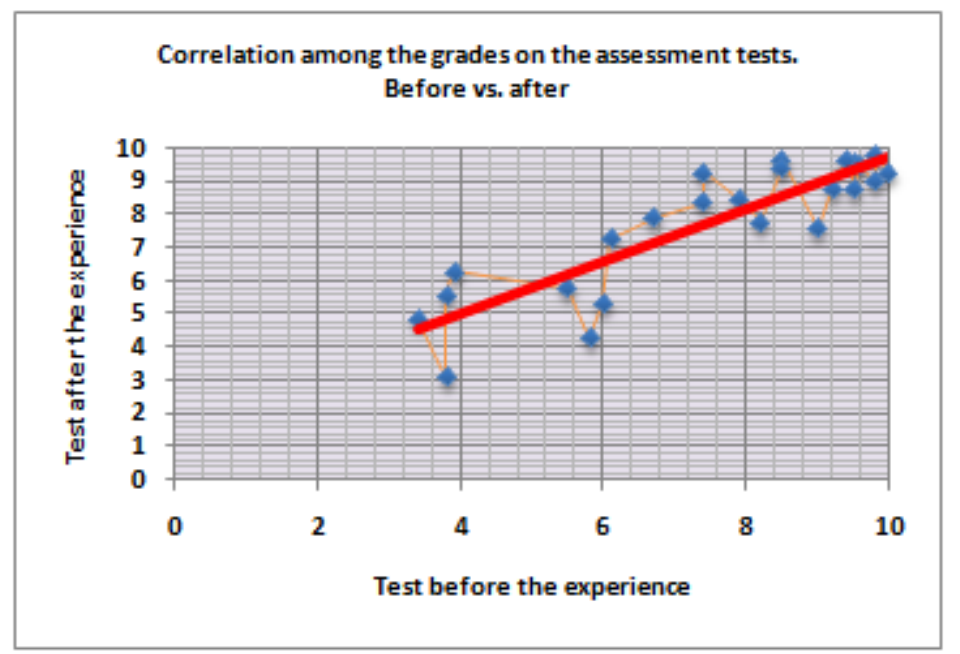

Figure 4. Correlation among the grades on the assessment tests before and after the concept map experience

\subsection{Satisfaction with the experience carried out}

In general, the assessments of the experience and its methodology have been very positive. Figure 5 and 6 show the percentage of students who answered each of the questions on the survey positively out of all the students surveyed in the two academic years studied. A total of 18 students completed the questionnaire in academic years 2014/2015 and 2015/2016.

With regard to satisfaction with the training received (Figure 5), a majority of the students $(82.4 \%$ and $88.9 \%$ ) characterize the activity as interesting, while $94.1 \%$ and $94.4 \%$ felt that they had learned how to create concept maps; in fact, after only two sessions, $41.2 \%$ and $50 \%$ of the students had decided to include this study technique in the course, stressing the usefulness of the methodology used and the need for more practice sessions with this methodology for the students to transform this technique into a learning strategy. $88.2 \%$ and $77.8 \%$ of the students stated that they liked working on the subject through this experience, and $52.9 \%$ and $61.1 \%$ would recommend the use of the technique, which lends credence to the idea that they liked the methodology, they have a positive opinion of this technique and it would be interesting to continue working on it with students. 


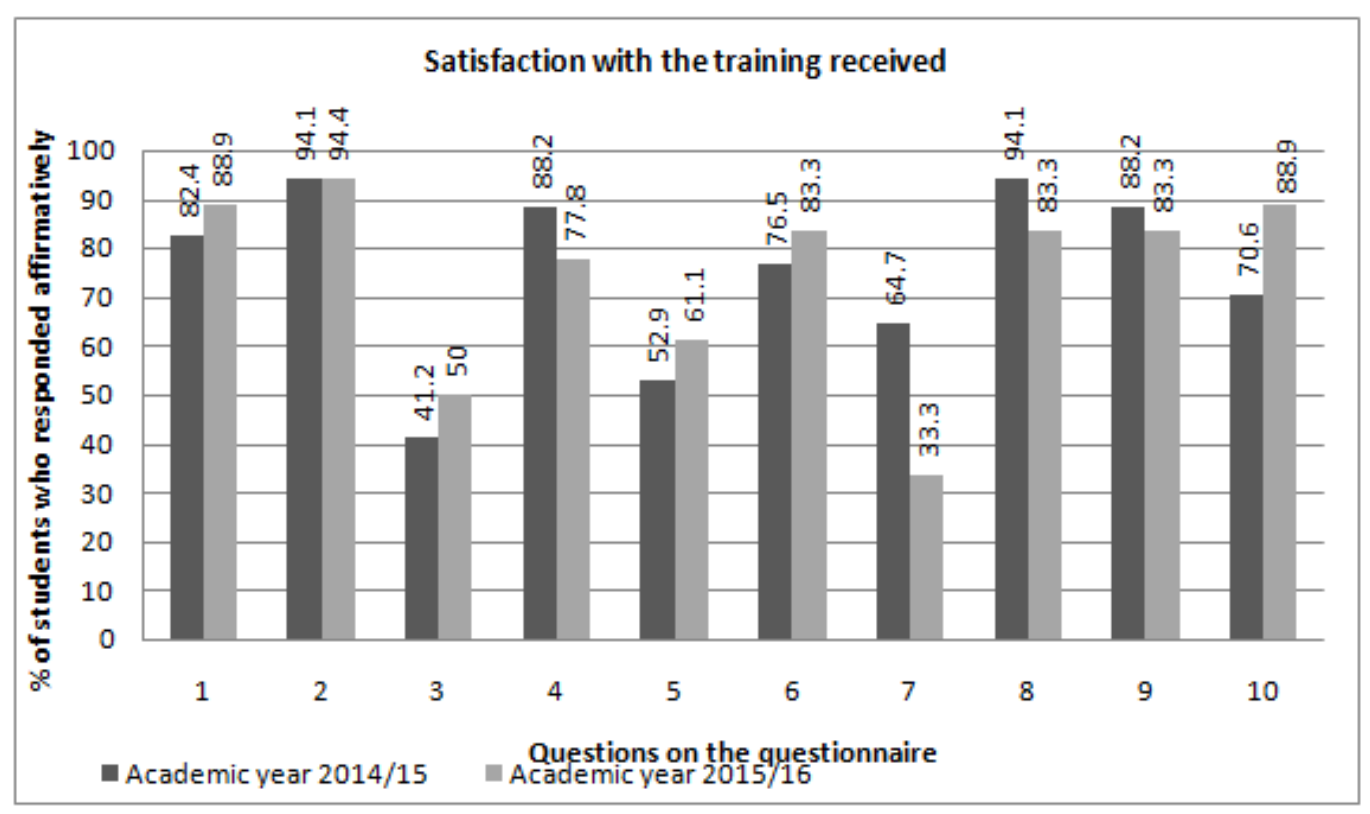

Figure 5. Results regarding satisfaction with the training received (questions 1-10 in Table 2)

Most of the students, $76.5 \%$ and $83.3 \%$, consider that this experience with the concept maps has helped them have a clearer notion about the main ideas of the text analyzed, thus improving their capacity for synthesis and comprehension of the information. This result is related to the $64.7 \%$ and $67 \%$ who state that they will start to use concept maps in the study of other subjects, once again revealing the interest by most of the students in this technique. However, it is surprising that during the 2015/16 academic year, only 33.3\% reported the intention to use concept maps to study other subjects.

Finally, $94.1 \%$ and $83.3 \%$ of the students believe that it was easy for them to create the concept maps, $88.2 \%$ and $83.3 \%$ consider them to be useful, and $70.6 \%$ and $88.9 \%$ believe that the time dedicated to performing the activities has been appropriate.

The results regarding the usefulness of the technique learned are shown in Figure 6. During the 2014/2015 academic year, only 5.9\% of the students stated that they use this technique during their daily studying, as opposed to $38.9 \%$ in 2015/2016.The vast majority of the students believe that this technique is useful for studying (88.2\% and $83.3 \%$ ). Only $11.8 \%$ and $33.3 \%$ of the students used this technique on a usual basis to study Natural Sciences. Comparing the previous results to those of question 3, where $41.2 \%$ and $50 \%$ stated that they would start to use this technique in the Natural Sciences course, we see that there has been an increase in the percentage of students who have decided to incorporate this technique in the course following this 
experience. The results obtained for question 15 confirm concept maps as a very useful technique to see relationships clearly among concepts, as stated by $88.2 \%$ and $72.2 \%$ of the students consulted. $94.1 \%$ and $72.2 \%$ consider that it is easy to create concept maps.

Most students believe that creating concept maps facilitates their learning (88.2\% and 78.8\%), and for $70.6 \%$ and $72.2 \%$ of the students, this work method does not require a greater effort on their behalf. Creating concept maps is perceived by students as a technique that facilitates the assimilation of the concepts $(88.2 \%$ and $77.8 \%$ ), and therefore it is surprising that during the course in which fewer students knew about the technique, it was perceived as being more useful for their future $(76.5 \%$, as opposed to $38.9 \%)$.

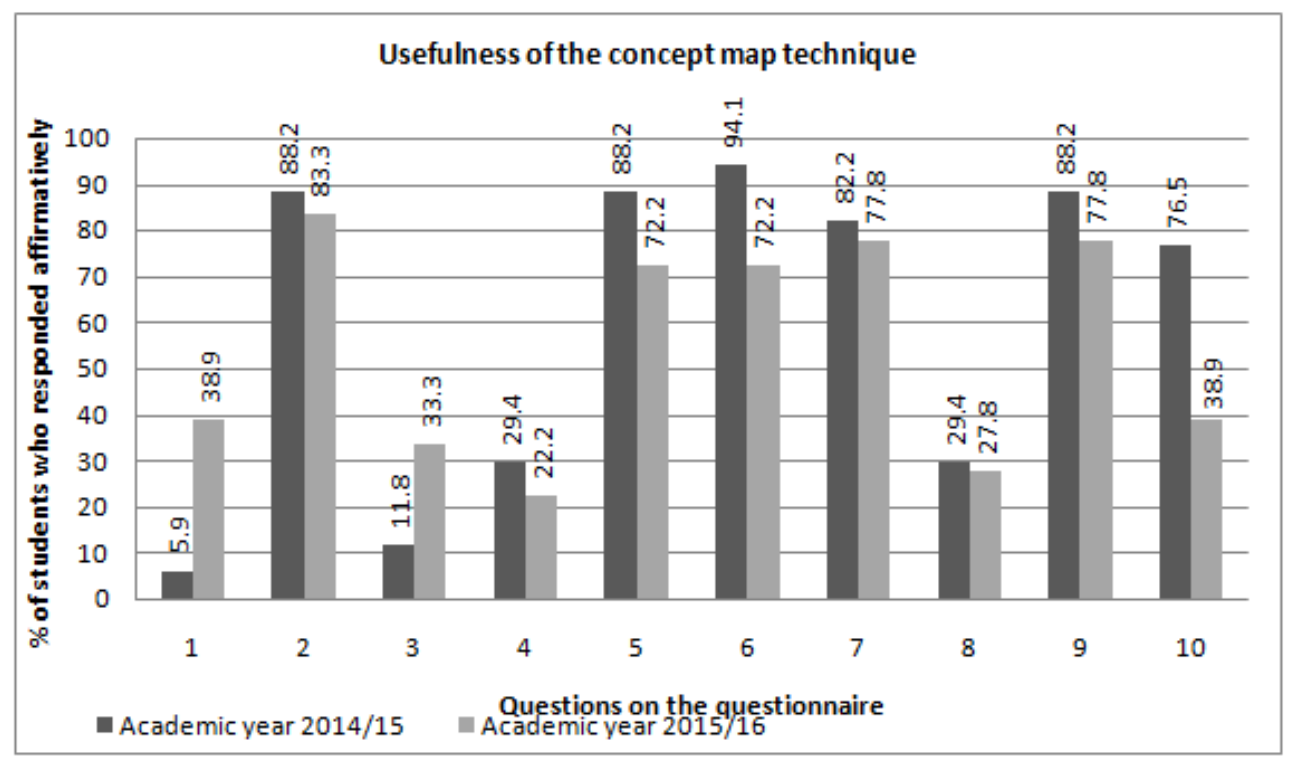

Figure 6. Results regarding the usefulness of the concept map technique (questions 11-20 in Table 3)

One of the future lines of action would be to extrapolate the concept maps experience to the rest of the school subjects. To find out the assessments of the students enrolled in the second year of Compulsory Secondary Education (ESO) regarding the most appropriate and interesting subjects in which to continue applying this technique, a question was included on the questionnaire that asked students to indicate the subjects in which they considered it most interesting to use concept maps. The results shown in Figure 7 indicate that the subjects considered most interesting by the students for the application of concept maps are Natural Sciences, Social Sciences, Geography and History, Spanish Language and Literature and Technology. 


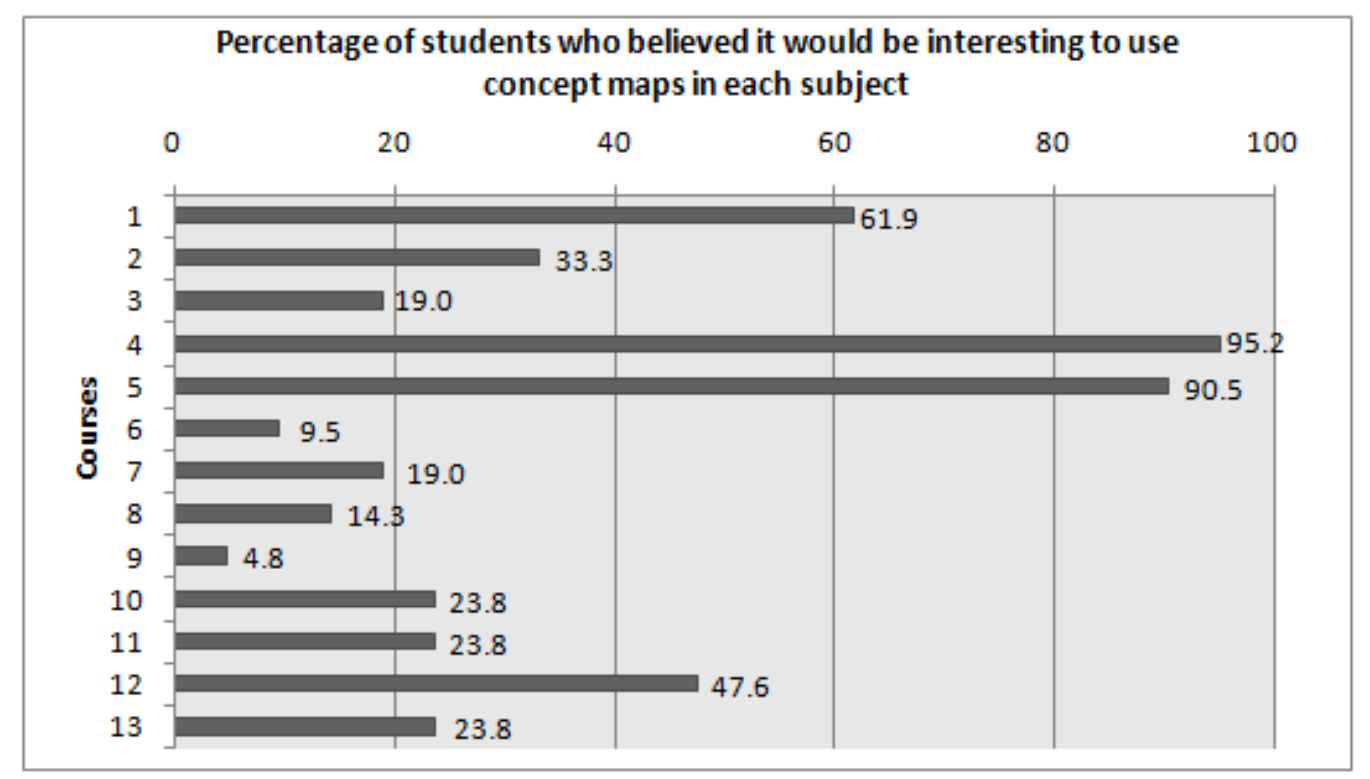

Figure 7. Application of concept maps in other subjects (courses in Table 3)

\section{Conclusions}

The use of concept maps in teaching provides a series of advantages: they promote agility and skill in organizing concepts in a specific subject area, have a great visual impact by showing the relationships among the main ideas in a simple, visually attractive manner, and graphically display the organization and connections among concepts and ideas. In this manner, they provide fast, easy comprehension of new concepts, promote the analysis and synthesis of ideas, and make it possible to explain in our own words what we have learned, which greatly facilitates comprehensive learning and boosts the development of reflective through, the incorporation of ideas and collaborative activity (Cabrera, Cuéllar, Landrián, Melis \& Gener, 2007). Empirical evidence exists that the introduction of concept maps promotes significant learning (Andueza, 2016).

Through the concept maps experience, students were shown how to work with the concept map technique as a strategy to help boost learning, and use it as a resource to help represent the set of contents as a whole. The grades earned by the students on the maps created allow us to assess this experience as satisfactory. The guided learning methodology teaches the students in a simple manner how to develop concept maps independently, based on a text. Based on the grades earned by students in activities 1 and 2, we can conclude that the guided learning methodology has enabled them to learn how to develop concept maps, although the differences in grades 
earned in the learning session and the session dedicated to applying the technique seem to indicate that more guided sessions are necessary in order to correctly learn how to develop concept maps.

The experience has generated interest in the technique among most of the students and in spite of not regularly using the technique to study the academic subject, this experience made developing concept maps easy and interesting for the students, and they learned how to create them correctly. The students view the concept map technique as useful and easy to perform; furthermore, they believe that it facilitates their autonomous learning, clarifies the relationship among concepts and aids in their assimilation, which they view as beneficial for their future. In this sense, the results presented are similar to those of other works in which the effectiveness of this technique was studied, which have also shown a high degree of satisfaction on behalf of the students when learning how to use this tool (Pontes, Serrano \& Muñoz, 2015, Ibáñez \& Gallego, 2017).

The application of this technique contributes to the acquisition of the learning to learn competence, autonomy and personal initiative, thus promoting improvements in the students' teaching-learning process, rendering it more effective (Ledo, Vidal \& Vialart, 2007). Even though the study comparing the means evidenced no significant results, an important improvement in the assessment tests was observed for the unit studied using concept maps for student with grades between 6 and 8.5. It would seem recommendable to include this methodology as a work method in the course, adding more sessions in which to practice this technique, so that students transform it into a learning strategy that leads to a significant improvement in the learning process, as indicated in studies by Soto, Chata and Jiménez (2014) and Mendonça (2013), in which it was determined that the application of the concept map technique had a positive influence on the significant learning process.

We can confirm that the results presented here reveal that the learning of this technique evidences positive changes in the students' attitude toward the learning process and the intention to incorporate this study technique, making it a learning strategy that will result in changes in academic performance. In this sense, the results presented in this study are related to the contributions made by other authors, such as Molina (2013), who claim that the use of this tool evidences changes in the experimental groups in terms of attitudes and academic performance. 


\section{References}

Adesope, O.O., \& Nesbit, J.C. (2009). A systematic review of research on collaborative learning with concept maps. In P. Lupion Torres (Ed.), Handbook of research on collaborative learning using concept mapping (pp. 238-255). USA: IGI Global. https://doi.org/10.4018/978-1-59904-992-2.ch012

Aguilar Tamayo, M. (2006). El mapa conceptual una herramienta para aprender y enseñar. Plasticidad y restauración neurológica, 5(1), 7-9, 13.

Andueza, A. (2016). La escritura como herramienta de aprendizaje significativo: Un cuasiexperimento en la clase de ciencias. Revista Complutense de Educación, 27(2), 653-668. https://doi.org/10.5209/rev_RCED.2016.v27.n2.46918

Bernardo Carrasco, J. (2004). Estrategias de aprendizaje, para aprender más y mejor. Madrid: Rialp

Cabrera, A.O., Cuéllar, F.D., Landrián, L.G., Melis, P.P., \& Gener, M.H. (2007). Los mapas conceptuales: Una poderosa herramienta para el aprendizaje significativo. Acimed, 15(5), 1.

Calero, M. (2009). Técnicas de estudio (pp. 23-24, 82). México: Alfaomega Grupo Editor.

De Benito, B., Darder, A., \& Salinas, J. (2012). Los itinerarios de aprendizaje mediante mapas conceptuales como recurso para la representación del conocimiento. Edutec, Revista Electrónica de Tecnologia Educativa, 39. Available online at: https://goo.gl/ kyufDv

Díaz-Barriga, F., \& Hernández, G. (2002). Estrategias docentes para un aprendizaje significativo, una experiencia constructivista. México: Mc Graw - Hill.

Edmonson, K. (2005). Assessing science understanding through concept maps. In J. Mintzes, J. Wandersee \& J. Novak (Eds.). Assesing science understanding: A buman contructivist view (pp 19-40). Estados Unidos: Elsevier Academic Press.

Gallego, M.J., Crisol, E., \& Gámiz, V. (2013). El mapa conceptual como estrategia de aprendizaje y de evaluación en la universidad. Su influencia en el rendimiento de los estudiantes. Enseñanz̧a \& Teaching, 31(2). Available online at: https://goo.gl/8n7S9D

Ibáñez, P., \& Gallego M.J. (2017). Diseño de una intervención formativa con mapas conceptuales en comunidades de aprendizaje. Píxel-Bit. Revista de Medios y Educación, 51, 97-109. https://doi.org/10.12795/pixelbit.2017.i51.06 
Kinchin, I.M. (2014). Concept mapping as a learning tool in higher education: A critical analysis of recent reviews. The Journal of Continuing Higher Education, 62(1), 3949. https://doi.org/10.1080/07377363.2014.872011

Ledo, M.V., Vidal, N.V., \& Vialart, D.R. (2007). Mapas conceptuales. Una estrategia para el aprendizaje. Revista Cubana de Educación Médica Superior, 21(3), 1-5.

Lucas-Molina, Pérez-Albéniz, A., Fonseca-Pedrero, EE., Ortuño-Sierra, J., Urraca, M.L., \& Santarén-Rosell, M. (2017). Fiabilidad y evidencias de validez de un instrumento para la evaluación de la calidad de los mapas conceptuales. ContextosEducativos, Extraordinario, 2, 119-130. https://doi.org/10.18172/con.3065

Martín, E. (2010). Aprender a Aprender. Una Competencia Básica Entre Las Básicas (p. 1). Universidad Autónoma de Madrid. Available online at:

http://www.cece.gva.es/consell/docs/jornadas/conferenciaelenamarti.pdf (Last access date: May 18th, 2015).

Mendonça, C. (2013). El uso de mapas conceptuales progresivos como estrategia de enseñanza y aprendizaje en la formación de profesores de Biología. Journal for Educators, Teachers and Trainers, 4(1), 107-121.

Molina, L.P. (2013). Los mapas conceptuales como herramientas de diagnóstico y tratamiento de errores conceptuales. JETT, 4(1), 122-131.

Novak, J.D. (1998). Conocimiento y aprendizaje. Los mapas conceptuales como herramientas facilitadoras para escuelas y empresas. Madrid: Alianza.

Novak, J.D. (2011). Learning, creating, and using knowledge: Concept maps as a facilitative tools in schools and corporations. Journal of e-learning and Knowledge Society, 6(3) 21-30.

Novak, J.D. (2013). Empowering learners and educators. Journal for Educators, Teachers and Trainers, 4(1). Available online at: https://goo.gl/ezEpyY

Novak, J.D., \& Gowin, B. (1988). Aprendiendo a aprender. Barcelona: Martínez Roca.

Novak, J.D., Mintzes, J., \& Wandersee, J. (2005). Learning, teaching and assessment: A human constructivist perspective. En J. Mintzes, J. Wandersee, \& J. Novak (Eds.), Assessing Science Understanding. A buman contructivist view (pp 1-13). San Diego: Elsevier Academic Press. https://doi.org/10.1016/B978-012498365-6/50003-2 
Orden ECD/65/2015, de 21 de enero, por la que se describen las relaciones entre las competencias, los contenidos y los criterios de evaluación de la educación primaria, la educación secundaria obligatoria y el bachillerato. Boletín Oficial del Estado,núm. 25, de 29 de enero de 2015, páginas 6986 a 7003. Available online at: https://www.boe.es/boe/dias/2015/01/29/pdfs/BOE-A2015-738.pdf

Pontes, A., Serrano, R., \& Muñoz, J.M. (2015). Los mapas conceptuales como recurso de interés para la formación inicial del profesorado de enseñanza secundaria: Opiniones del alumnado de ciencias sociales y humanidades (Concept maps as a resource of interest for initial training of secondary school teachers: Opinions of students in the area of social sciences and humanities). Educación XXI, 18(1), 99-124. https://doi.org/10.5944/educXXI.18.1.12313

Romance, N.R., \& Vitale, M.R. (2013). A Research-Based Instructional Model for Integrating Meaningful Learning in Elementary Science and Reading Comprehension. In N. Stein \& S. Raudenbush (Eds.), Developmental Cognitive Science Goes to School (pp 127-142). New York: Routledge.

Soto C., Chata, H., \& Jiménez, W. (2014). La utilización de mapas conceptuales y mentales en el aprendizaje significativo. Revista de Investigaciones de la UNAD, 13(2), 63-77.

https://doi.org/10.22490/25391887.1146

Vázquez, E., \& López, E. (2016). Experiencia didáctica con mapas conceptuales interactivos con estudiantes universitarios sobre las áreas de intervención sociolaboral del educador social. Aula de Encuentro, 18(1), 5-23.

Published by OmniaScience (www.omniascience.com)

Journal of Technology and Science Education, 2017 (www.jotse.org)

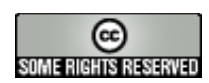

Article's contents are provided on an Attribution-Non Commercial 3.0 Creative commons license. Readers are allowed to copy, distribute and communicate article's contents, provided the author's and JOTSE journal's names are included. It must not be used for commercial purposes. To see the complete licence contents, please visit http://creativecommons.org/licenses/by-nc/3.0/es/ 